\title{
Inhibition of Messenger Ribonucleic Acid Synthesis in Escherichia coli by Thiolutin
}

\author{
GEORGE G. KHACHATOURIANS ${ }^{1}$ AND DONALD J. TIPPER \\ Department of Microbiology, University of Massachusetts Medical School, Worcester, Massachusetts 01605
}

Received for publication 10 June 1974

\begin{abstract}
Thiolutin, at concentrations of 5 to $40 \mu \mathrm{g} / \mathrm{ml}$, inhibited the induced synthesis of $\beta$-galactosidase in Escherichia coli CA8000. Thiolutin had no effect on the rate of in vitro hydrolysis of $\boldsymbol{o}$-nitrophenyl- $\beta$-D-galactoside by purified $\beta$-galactosidase. Examination of the effects of thiolutin on the kinetics of appearance of $\beta$-galactosidase in the presence and absence of rifampin in induced $E$. coli cells indicated that thiolutin interferes with the transcription process at the level of elongation of messenger ribonucleic acid (mRNA) chains. The data indicated that, in the presence of thiolutin, $\beta$-galactosidase mRNA has a half-life of $1.6 \mathrm{~min}$ and that the first completed $\beta$-galactosidase mRNA is produced about $1.5 \mathrm{~min}$ after induction. These data are consistent with estimates of transcription time and messenger half-life obtained by conventional means, and suggest that thiolutin does not affect translation of mRNA or its breakdown in vivo. After removal of thiolutin, cells fully regained the ability to be induced for synthesis of $\beta$-galactosidase within $10 \mathrm{~min}$, but mRNA which was incomplete at the time of thiolutin addition did not subsequently become functional.
\end{abstract}

We have recently shown that thiolutin (TL) inhibits the growth of Escherichia coli by primary effects on ribonucleic acid and protein synthesis $(6,9 a)$. The exact mode of action and the target(s) of the drug in $E$. coli are unknown at present.

To further characterize the inhibitory effect(s) of TL, we have assessed its action on induced $\beta$-galactosidase synthesis. The kinetics of this process in $\mathrm{lac}^{+} E$. coli are well understood and have been used to study the mode of action of rifampin (RIF) and of other inhibitors of in vivo transcriptional and translational (26) activities in bacteria, notably by Kepes and his collaborators $(4,5,9$, and references therein). The results presented in this report indicate that TL inhibits protein synthesis as a secondary consequence of inhibition of messenger ribonucleic acid (mRNA) synthesis at the stage of chain elongation.

\section{MATERIALS AND METHODS}

Bacterial growth. Wild-type $E$. coli CA8000 (referred to as strain GK19) was grown in medium $\mathrm{E}$ (27) supplemented with $0.4 \%$ (wt/vol) glycerol, $0.2 \%$ (wt/ vol) Casamino Acids, and $2 \mu \mathrm{g}$ of thiamine-hydrochloride per $\mathrm{ml}$ (medium E-glycerol- $\mathrm{B}_{1}$ ) at $37 \mathrm{C}$ in a water-bath shaker (New Brunswick Metabolyte Shaker, New Bunswick Scientific, New Brunswick,

${ }^{1}$ Present address: Department of Bacteriology, Faculty of Medicine, University of Saskatchewan, Saskatoon, S7N OWO, Canada.
N.J.). The cells were induced at a cell density of $2 \times$ $10^{8}$ to $4 \times 10^{8}$ cells $/ \mathrm{ml}$.

Increase in permeability of cells. To increase the permeability of $E$. coli cells to RIF, cells were treated with ethylenediaminetetraacetic acid (EDTA) as described by Jacquet and Kepes (5), whose procedure is a slight modification of that of Leive (12). Exponentially growing cells $(25$ to $50 \mathrm{ml})$ at an absorbancy at $600 \mathrm{~nm}\left(A_{600}\right)$ of 0.8 to 1.0 were filtered through 0.45- $\mu \mathrm{m}$ membrane filters (Millipore Corp., Bedford, Mass.), rinsed twice with $.0 .12 \mathrm{M}$ tris(hydroxymethyl)aminomethane-hydrochloride buffer, $\mathrm{pH} 7.8$, and resuspended in the same buffer at $1 / 10$ the initial culture volume. EDTA (final concentration $1 \mathrm{mM}$ ) was added to the suspension, and cells were shaken vigorously at $37 \mathrm{C}$ for $1 \mathrm{~min}$. EDTA action was terminated by diluting cells 10 -fold into warmed E-glycerol-B $B_{1}$ medium. After this treatment, $E$. coli again became impermeable to antibiotics (actinomycin D, RIF, and puromycin) $15 \mathrm{~min}$ after EDTA treatment at $37 \mathrm{C} \mathrm{(5).}$

Radioactive labeling. Samples (100 $\mu$ liters) of cultures labeled with $\left[{ }^{3} \mathrm{H}\right]$ uridine $(0.01 \mu \mathrm{Ci} / \mathrm{mmol})$, [ ${ }^{14} \mathrm{C}$ ]uracil $(0.01 \mu \mathrm{Ci} / \mathrm{mmol})$, or $\left[{ }^{3} \mathrm{H}\right]$ leucine $(0.01$ $\mu \mathrm{Ci} / \mathrm{mmol}$ ) were placed on $3 \mathrm{MM}$ filter paper (W. \& R. Balson Ltd., England) and submerged in 10\% trichloroacetic acid for 1 to $2 \mathrm{~h}$. Subsequently, filters were washed twice with $5 \%$ trichloroacetic acid and once with $95 \%$ ethanol, and were air-dried before counting in a toluene-based scintillation liquid (9a) with a $\mathrm{Nu}$ clear-Chicago Isocap 300 scintillation counter $(\mathrm{Nu}$ clear-Chicago Corp., Des Plaines, Ill.).

Chemicals. TL was a gift from Nathan Belcher, Pfizer, Inc., Groton, Conn. TL was prepared at 2 $\mathrm{mg} / \mathrm{ml}$ in dimethylsulfoxide and used at the final concentrations indicated in the text. Isopropyl- $\beta$-D- 
thiogalactoside (IPTG) was purchased from Calbiochem (Los Angeles, Calif.). Chloramphenical (CAM), $\mathrm{RIF}$, and 0 -nitrophenyl- $\beta$-D-galactoside (ONPG) were obtained from Sigma Chemical Co., St. Louis, Mo. Radioactive compounds were obtained from New England Nuclear, Boston, Mass.

Determination of $\beta$-galactosidase synthesizing capability. $\beta$-galactosidase was assayed in toluenetreated cells as described by Miller (15). Exponentially growing cells were induced with $10^{-2}$ or $10^{-3} \mathrm{M}$ IPTG. At timed intervals, $0.5 \mathrm{ml}$ of culture was removed, treated with toluene (1 to 2 drops), and mixed with a Vortex mixer for $45 \mathrm{~s}$. Tubes were then incubated for 30 to $40 \mathrm{~min}$ at $37 \mathrm{C}$ to evaporate the toluene and were subsequently placed in a water bath at $28 \mathrm{C}$ for the $\beta$-galactosidase assays.

Assay for $\beta$-galactosidase. All samples for $\beta$ galactosidase assay $(1 \mathrm{ml})$ contained 0.1 to $0.8 A_{600}$ units of toluene-treated cells. ONPG $(4 \mathrm{mg} / \mathrm{ml}, 200$ $\mu$ liters) was added, and the reaction was stopped by the addition of $0.5 \mathrm{ml}$ of $1 \mathrm{M} \mathrm{Na}_{2} \mathrm{CO}_{3}$. Absorbance at 420 and $550 \mathrm{~nm}$ was determined, and enzyme units per milliliter were calculated as follows: $10^{3} \times\left[A_{420}-\right.$ $\left.A_{550}\right] \times$ (assay time in $\mathrm{min} \times$ culture volume in $\mathrm{ml} \times$ culture $\left.A_{600}\right)^{-1}$.

For the study of in vitro effects of TL on purified $\beta$-galactosidase from $E$. coli, $2.8 \times 10^{-3}$ enzyme units (Crystalline Suspension, Grade IV, Sigma Chemical Co.) per $\mathrm{ml}$ in minimal salts medium $\mathrm{E}$ was incubated with $20 \mu \mathrm{g}$ of TL per $\mathrm{ml}$ in a Zeiss PMQ11 spectrophotometer adjusted to $37 \mathrm{C}$ with a Haake circulating water bath (Sargent Welsh, Springfield, N.J.). Reactions were initiated by the addition and mixing of ONPG, which was accomplished in 10 to $12 \mathrm{~s}$. The rate of formation of $o$-nitrophenol was followed by monitoring the changes of $A_{420}$.

Recovery from TL inhibition. TL was added to exponentially growing cultures. After appropriate times, the inhibitor was removed by filtering the cells on a $0.45-\mu \mathrm{m}$ membrane filter (GS type). The cells were washed once with TL-free medium which had been prewarmed to $37 \mathrm{C}$ ( 5 times the original volume of the treated sample). Filters containing the cells were placed in drug-free medium and mixed vigorously to resuspend the cells, and the whole suspension was then transferred to flasks at $37 \mathrm{C}$. Cells were incubated for $5 \mathrm{~min}$ before measuring various metabolic activities.

\section{RESULTS}

ONPG hydrolysis in the presence of TL. It has been shown that TL inhibits yeast RNA polymerases in vitro. Maximal inhibition is seen after preincubation of enzyme and TL for $5 \mathrm{~min}$ at $30 \mathrm{C}$, and under these conditions $50 \%$ inhibition is produced by $3 \mu \mathrm{g}$ of TL per $\mathrm{ml}(25)$. It was essential for the interpretation of the data presented in this paper to demonstrate that TL has no direct effect on the $\beta$-galactosidase of $E$. coli. Figure 1 shows the kinetics of ONPG hydrolysis under our standard assay conditions, using purified $E$. coli $\beta$-galactosidase. It is clear that even lengthy preincubation of the enzyme with TL and its presence during the assay has no noticeable effect on its activity. The enzyme is also insensitive to TL action when added during the time course of hydrolysis of the substrate, ONPG.

Residual $\beta$-galactosidase synthesis in the presence of TL. Within 3 to $4 \mathrm{~min}$ after induction of an exponential-phase culture of $E$. coli at $37 \mathrm{C}$ with $10^{-3} \mathrm{M}$ IPTG, the rate of synthesis of $\beta$-galactosidase is maximal $(5,9$, 18). Cultures treated with increasing concentrations of TL shortly after this steady state is achieved $(5 \mathrm{~min})$ synthesize the residual amounts of $\beta$-galactosidase shown in Table 1 . Near maximal effect is seen with 5 to $20 \mu \mathrm{g}$ of TL per $\mathrm{ml}$, and this effect is evidently rapid. In the untreated culture, a $75 \%$ increase in activity over that present at $5 \mathrm{~min}$ is achieved within an additional $1.5 \mathrm{~min}$.

Addition of $20 \mu \mathrm{g}$ of TL per ml to a culture of strain GK19 caused an immediate $95 \%$ reduction in the rate and amount of $\left[{ }^{14} \mathrm{C}\right]$ uracil incorporated into RNA. In contrast, protein synthesis, as measured by the incorporation of radioactive leucine, continued for several minutes before stopping. Cultures of strain GK19

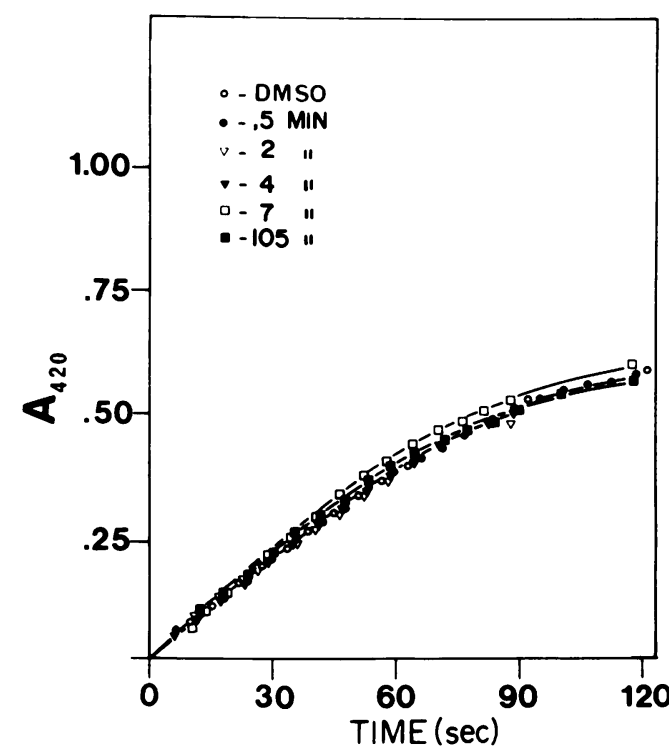

Fig. 1. Kinetics of ONPG hydrolysis by $\beta$-galactosidase in the presence of $T L$. The rate of hydrolysis of ONPG is shown for purified $\beta$-galactosidase pretreated with dimethylsulfoxide (1\%) for $10 \mathrm{~min}$ or with $T L(20 \mu \mathrm{g} / \mathrm{ml})$ in $1 \%$ dimethylsulfoxide for the indicated times at $37 \mathrm{C}$. Further details are given in Materials and Methods. 
TABLE 1. Inhibition of $\beta$-galactosidase synthesis in vivo $^{a}$

\begin{tabular}{l|c|c|c}
\hline $\begin{array}{c}\text { Thiolutin } \\
(\mu \mathrm{g} / \mathrm{ml})\end{array}$ & $\begin{array}{c}\text { Time of assay } \\
(\mathrm{min})\end{array}$ & $\begin{array}{c}\text { Enzyme } \\
\text { activity } \\
(\mathrm{U} / \mathrm{ml})\end{array}$ & $\begin{array}{c}\text { Residual } \\
\text { enzyme }^{\circ} \\
\text { formed } \\
(\%)\end{array}$ \\
\hline 0 & 1 & 26.3 & \\
$0\left(\mathrm{Me}_{2} \mathrm{SO}^{c}\right)$ & 5 & 195.0 & \\
$0\left(\mathrm{Me}_{2} \mathrm{SO}^{\mathrm{s}}\right)$ & 20 & 1135.0 & 482 \\
1 & 20 & 466 & 138 \\
5 & 20 & 350 & 79.5 \\
10 & 20 & 350 & 79.5 \\
20 & 20 & 332 & 70.2 \\
40 & 20 & 260 & 33.3 \\
\hline
\end{tabular}

a Cells of strain GK19 were grown in medium E-glycerol- $B_{1}$, induced with IPTG $\left(10^{-3} \mathrm{M}\right)$ at time zero. $\mathrm{Me}_{2} \mathrm{SO}(1 \%)$ or thiolutin at the indicated concentrations was added $5 \mathrm{~min}$ later to samples of induced cells. $\beta$-Galactosidase activity was assayed after incubation for 15 additional minutes.

- Data are presented as percent increase of enzyme activity during this 15 -min incubation.

${ }^{c} \mathrm{Me}_{2} \mathrm{SO}$, dimethylsulfoxide.

were also treated with $20 \mu \mathrm{g}$ of TL per $\mathrm{ml}$ and subsequently given $1 \mathrm{mM}$ IPTG to induce the synthesis of mRNA from the lac operon. In spite of continued uptake of label, we failed to detect a similar and corresponding synthesis of $\beta$ galactosidase activity (Table 2 ). Thus, the residual $5 \%$ incorporation of uracil in the presence of TL may represent stable RNA synthesis and incorporation into deoxyribonucleic acid (DNA), which continues to be synthesized in the presence of TL (9a).

Recovery of capacity for $\beta$-galactosidase synthesis. Cultures treated with TL recover their capacity for protein, RNA, and DNA synthesis and cell division when the drug is washed out $(6,9 a)$. Figure 2 shows the induction of $\beta$-galactosidase in cells that had been washed free of drug after 2, 6, and 15 min of treatment with $20 \mu \mathrm{g}$ of TL per ml. The untreated control synthesized $10 \mathrm{U}$ per $\mathrm{ml}$ per min after the first $10 \mathrm{~min}$. The initial rate of synthesis in TLtreated cells is reduced, with a lag that increases with increasing time of exposure to TL. In this instance, the culture treated for 15 min shows a 10-min lag, after which synthesis slowly accelerates, and by $30 \mathrm{~min}$ attains the same rate as in the untreated control. Bacteria recovering from TL treatment start synthesis of RNA, DNA, and protein within a few minutes (9a), and the rate of RNA synthesis, as measured by the incorporation of $\left[{ }^{3} \mathrm{H}\right.$ ]uridine in this same experiment, returned to the rate of incorporation in untreated controls after 1,10 , and $15 \mathrm{~min}$ in
TABLE 2. Comparison of $\beta$-galactosidase and RNA synthesis in vivo in thiolutin-treated cells ${ }^{a}$

\begin{tabular}{c|c|c}
\hline $\begin{array}{c}\text { Time of addition } \\
\text { (min) }\end{array}$ & $\begin{array}{c}\beta \text {-Galactosidase } \\
\text { activity }^{b} \\
(\%)\end{array}$ & $\begin{array}{c}\text { RNA synthesis } \\
(\%)\end{array}$ \\
\hline 0.50 & 1.47 & 0.25 \\
5 & 0.91 & 0.71 \\
10 & 0.20 & 1.00 \\
30 & 0.18 & 2.45 \\
60 & 0 & 3.71 \\
90 & 0 & 5.87 \\
120 & 0 & 7.14 \\
150 & 0.42 & 7.78 \\
\hline
\end{tabular}

${ }^{a}$ Cells of GK19 were grown in medium E-glycerol$\mathrm{B}_{1}$ and were treated with $20 \mu \mathrm{g}$ of thiolutin per $\mathrm{ml}$ (in $1 \%$ dimethylsulfoxide) at zero time. [ $\left.{ }^{3} \mathrm{H}\right]$ uracil $(2.5$ $\mu \mathrm{Ci} / \mathrm{ml}$ ) was added at the same time. Subsequently, samples of treated cells were induced with IPTG (1 $\mathrm{mM})$ at the indicated times. Twenty minutes after the addition of the inducer, cells were assayed for $\beta$-galactosidase activity and were incorporated radioactively.

${ }^{b}$ Enzyme activities corrected for the (basal) uninduced enzyme activities are presented as percent of that produced in $20 \mathrm{~min}$ in a culture treated with dimethylsulfoxide (1\%) alone.

c Total RNA synthesis was determined from the uptake of $\left[{ }^{3} \mathrm{H}\right]$ uracil into trichloroacetic acid-precipitable fraction of cells.

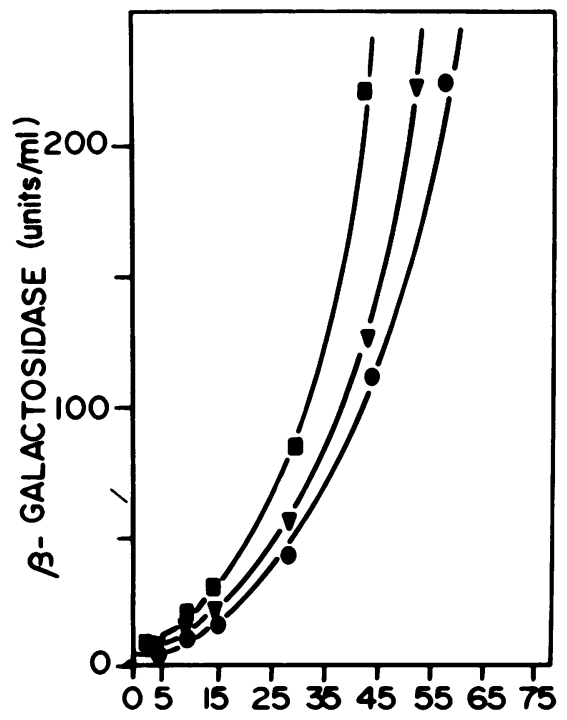

Fig. 2. Induced synthesis of $\beta$-galactosidase in $E$. coli recovering from $T L$ treatment. Exponentially grown cells of strain GK19, after incubation with TL $(20 \mu \mathrm{g} / \mathrm{ml})$ for $2(\square), 6(4)$, and $15(0) \mathrm{min}$, were washed and resuspended in drug-free medium. At 0 min, IPTG $\left(10^{-3} M\right)$ was added, and the levels of $\beta$ galactosidase were determined at the indicated times. 
cultures treated for 2,6 , and $15 \mathrm{~min}$, respectively. These lag times are less then those for recovery of $\beta$-galactosidase synthesis (Fig. 2).

Like $\beta$-galactosidase synthesis and in contrast to RNA synthesis, cell division in cultures treated with TL is delayed (9a). In this experiment, the lag in regaining the rate of cell division shown by the untreated control was 15 , 25 , and $35 \mathrm{~min}$ after treatment with TL for 2,6 , and $15 \mathrm{~min}$, respectively.

The wave of $\beta$-galactosidase synthesis in the presence of TL. The kinetics of $\beta$-galactosidase synthesis in induced cultures in the presence of TL is shown in Fig. 3A. In two separate experiments, cultures of strain GK19 were induced with $5 \times 10^{-3} \mathrm{M}$ IPTG, and TL was added at 90,180 , and $300 \mathrm{~s}$ after induction. The residual synthesis of $\beta$-galactosidase (Fig. 3A) declines to a halt 5 to 7 min after the addition of the drug. Since no $\beta$-galactosidase is made if TL is added before induction (above) and the addition of TL stops synthesis of functional $\beta$-galactosidase mRNA within $0.5 \mathrm{~min}$ (Table $2)$, this result establishes that translation of preformed mRNA into a complete polypeptide, and its transformation into a functional oligomer (28), continues in the presence of TL and that the effect of TL must be on mRNA synthesis.

Analysis of the half-life of the coding capacity of mRNA as assessed by the method of Kepes (8) gave a result of $1.6 \mathrm{~min}$, independent of the time of addition of TL (Fig. 3B). This is consistent with the conventional estimates of lac mRNA half-lives $(1,5,7,9,23)$. These analyses indicate that no unusual changes in the degradation of mRNA occurs in TL-treated cultures.

Absence of a permeability barrier to $T L$. By binding to RNA polymerase, RIF specifically blocks the initiation of RNA chains but not the completion of transcription in progress (24). Thus, RIF is a useful means of estimation of enzyme-synthesizing capacity in bacteria $(3,5$, $19,23)$. As a consequence of the relative impermeability of wild-type $E$. coli cells to RIF, complete inhibition of transcription occurs only when very high levels $(100 \mu \mathrm{g} / \mathrm{ml}$ or more $)$ of the drug are used $(20,21)$. This obstacle is eliminated by reduction of the permeability barrier
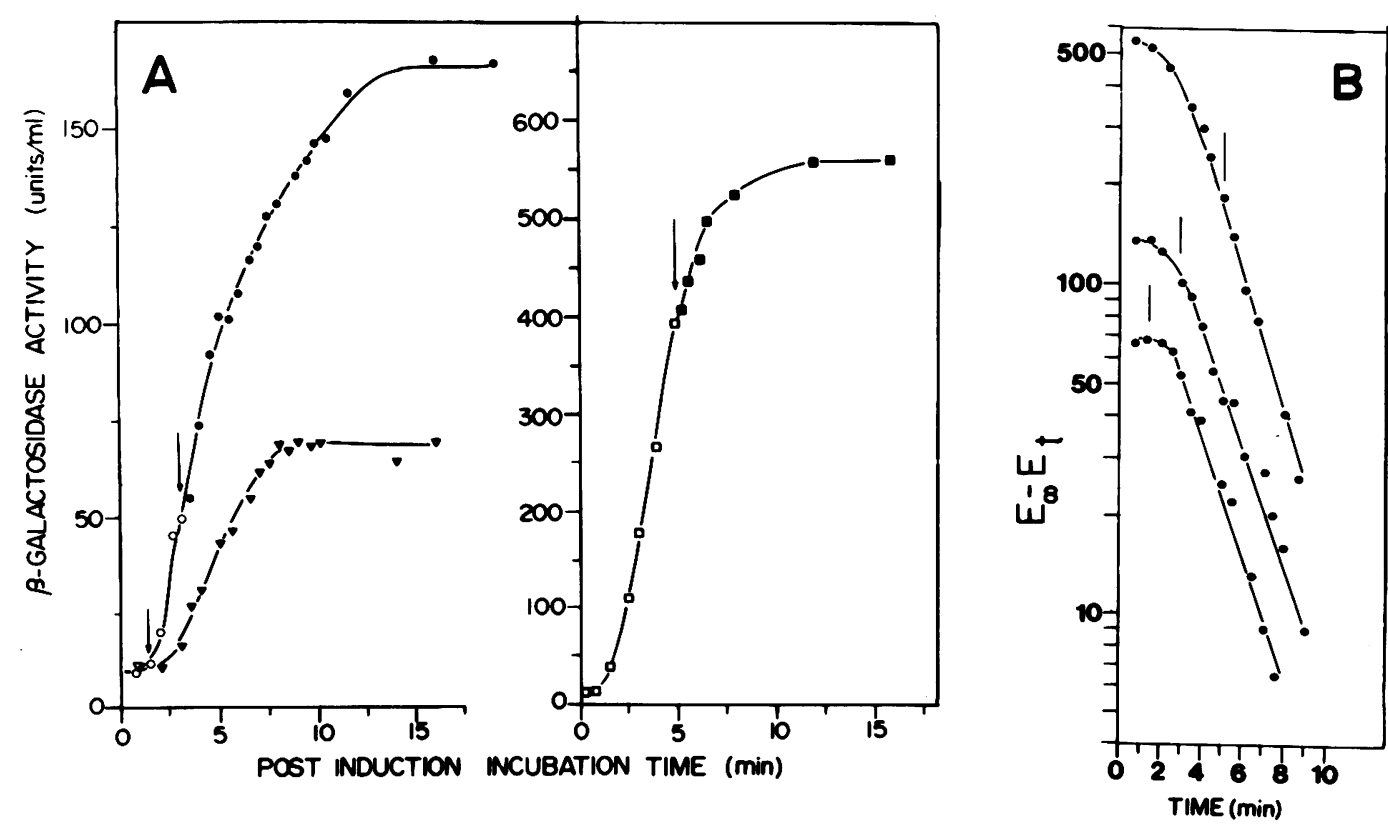

Fig. 3. Effect of TL on transcription of $\beta$-galactosidase $m R N A$ in vivo. (A) Cells induced with IPTG (1 mM) at 0 time were treated with $T L(20 \mu \mathrm{g} / \mathrm{ml})$ at $1.5(\nabla), 3(0)$, and $5(\square) \mathrm{min}$ (shown by vertical arrows), and $1-\mathrm{ml}$ samples were removed for measurement of $\beta$-galactosidase activity at the indicated intervals. $(B)$ The decay of $\beta$-galactosidase synthesizing ability is presented by plotting the difference between the $\beta$-galactosidase activity present at the plateau $\left(E_{\infty}\right)$ and at time $t\left(E_{t}\right)$ on a logarithmic scale. The half-life for $50 \%$ decrease in $\left(E_{\infty}-E_{t}\right)$ is 1.55 to $1.65 \mathrm{~min}$ in each case. 
by EDTA treatment $(5,12,20)$ or by using more permeable mutants sensitive to low levels of RIF $(11,14,19,23)$.

In contrast to other inhibitors of RNA synthesis, for example, actinomycin D, RIF, and streptolydigin, which efficiently penetrate the $E$. coli cell only when its permeability barrier has been partially removed, TL blocks RNA synthesis irrespective of the presence or absence of the permeability barrier. The capacity of exponential cultures of strain GK19 that had been rendered more permeable by EDTA treatment to synthesize $\beta$-galactosidase in the presence of TL was compared with that of non-EDTAtreated cells treated with TL. The amount of enzyme synthesized in the presence of TL in each case was approximately the same, and, when plotted, the curves were superimposable (Fig. 4). It is apparent that TL can as easily penetrate untreated as treated cells.

Examination of the early kinetics of induced enzyme synthesis in the presence of TL (Fig. 4, insert) also reveals no difference between treated and untreated cells. The insert, furthermore, permits estimation of the sum of the times for TL to take effect and for the synthesis of mRNA molecules containing complete $\beta$ galactosidase mRNA (assuming TL inhibits polymerization of preinitiated RNA chains; see below). This is approximately $1.5 \mathrm{~min}$, equal to the known transcription time of the lac $z$ gene $(5,9,13)$. Thus, TL at $20 \mu \mathrm{g} / \mathrm{ml}$ exerts its effect on transcription very rapidly.

TL prevents elongation of lac mRNA. If RIF reacts completely and rapidly with all RNA polymerase molecules (21), residual enzyme synthesis in the presence of RIF will be due to translation of all initiated mRNAs, both complete and incomplete, at the time of RIF addition. The extent of translation of each mRNA molecule will depend on the number of translational initiations achieved before degradation of the $5^{\prime}$ end of the mRNA commences. Under steady-state conditions where the rate of transcription and translation is maximal and constant, if the rate of translation initiation is independent of the stage of completion of the mRNA (the translational and transcriptional times for the lac $z$ gene are both about $1.5 \mathrm{~min}$ ) and if $R$ is the half-life of completed messenger and $T$ is the transcription time, an efficient inhibitor of RNA polymerization which does not affect mRNA breakdown should allow $X \%$ as much additional synthesis of $\beta$-galactosidase (after its addition) as does RIF, where $X=100$ $R(R+T)^{-1}$. Since $T$ and $R$ are both about 1.5 $\min$ for the lac $z$ gene $(1,5,7,9,23), X=50 \%$.

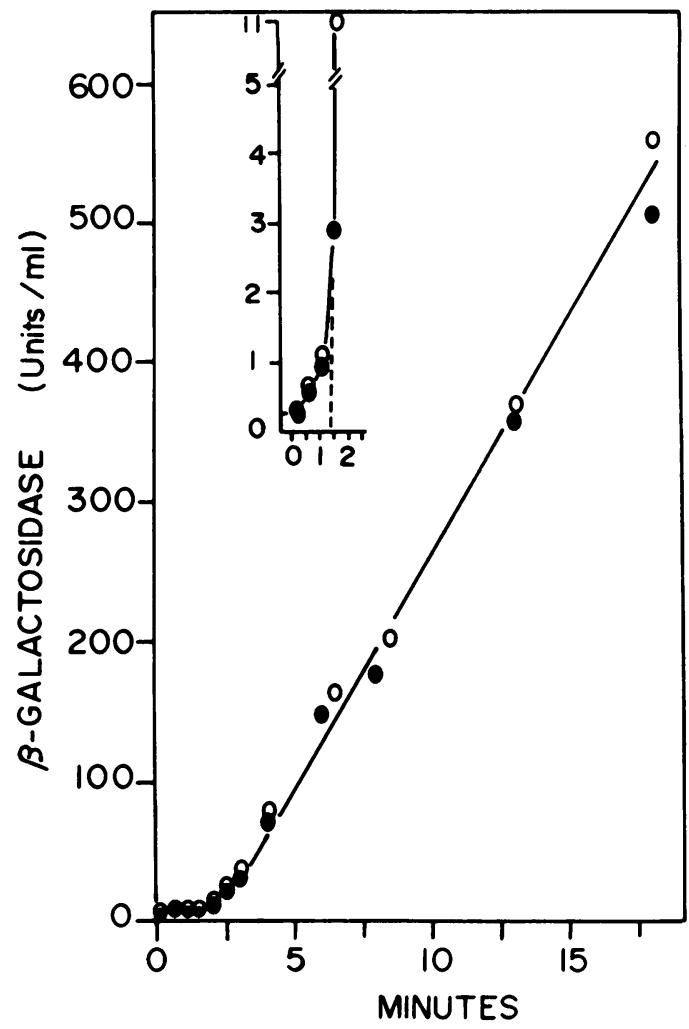

Fig. 4. Synthesis of $\beta$-galactosidase in normal and EDTA-treated cells treated with TL. Exponential cells of strain GK19 were washed with tris(hydroxymethyl)aminomethane-hydrochloride. One half (O) was rendered permeable by treatment with EDTA, and the other half (O) was not. After resuspension in prewarmed medium, IPTG was added at 0 min, and samples were removed at the indicated times and incubated with TL for an additional $20 \mathrm{~min}$. The final level of $\beta$-galactosidase activity is presented as a function of time of addition of TL. The insert shows $\beta$-galactosidase synthesis during the first $2 \mathrm{~min}$ after induction.

Even under non-steady-state conditions, the residual synthesis of $\beta$-galactosidase in the presence of RIF and an inhibitor of RNA elongation should be equal to that synthesized in parallel, uninhibited cultures in $(T+R)$ and $R$, or 3 and $1.5 \mathrm{~min}$, respectively. Thus, the step in RNA synthesis inhibited by TL, which apparently does not affect mRNA breakdown (above), can be deduced from the comparative kinetics of $\beta$-galactosidase synthesis in the presence of RIF and TL.

A culture of strain GK19 was treated with EDTA and induced with IPTG at zero time. Two minutes later, portions of the induced cells 
were treated with RIF or TL. Samples were removed at 30 -s intervals for determination of $\beta$-galactosidase activity. The results are shown in Fig. 5A. After the addition of TL, functional enzyme synthesis continues for nearly $1 \mathrm{~min}$ at a near normal rate. After $4 \mathrm{~min}$, TL-treated cells stop synthesizing any further $\beta$-galactosidase. The final amount of enzyme synthesized extrapolates to that of the control culture at 3.5 min postinduction time, $1.5 \mathrm{~min}$ after TL addition. RIF treatment allows functional enzyme synthesis over a period of 8 to $10 \mathrm{~min}$ (plateau time), the final amount of enzyme being equivalent to that synthesized by the control culture in 3 min after RIF addition (Fig. 5A). Samples of the control and drug-treated cultures were also mixed with $\left[5-{ }^{3} \mathrm{H}\right]$ uridine at zero time for the assessment of total RNA-synthesizing capacity of the cultures. The results are shown in Fig. 6B. RIF caused rapid and almost complete inhibition of RNA synthesis under the conditions of this experiment. The effect of TL was also immediate, but not complete.

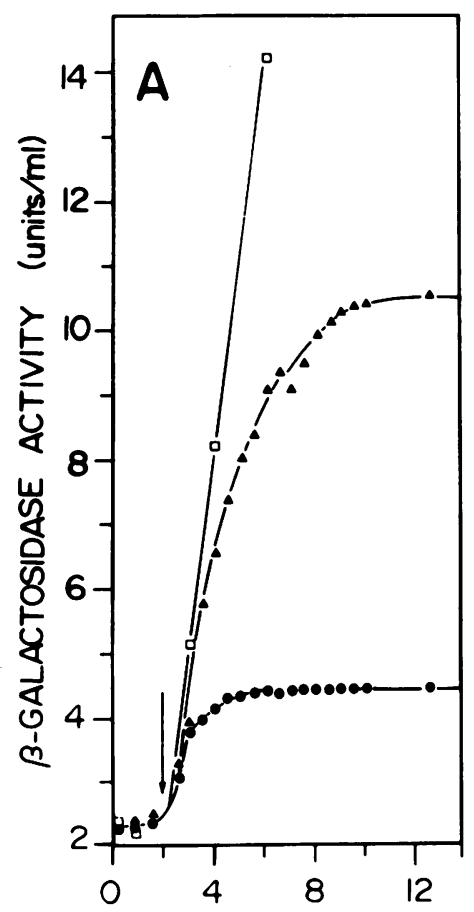

It is clear that TL action distinctly differs from that of RIF, and these data are consistent with inhibition of elongation of preinitiated mRNA chains by TL. The radioactive [5${ }^{3} \mathrm{H}$ ]uridine incorporation data (Fig. 5B) show that some incorporation continues in TLtreated cultures, in the absence of synthesis of functional $\beta$-galactosidase mRNA.

We have also compared the capacity of induced cells to synthesize $\beta$-galactosidase from preformed mRNA in the presence of TL, RIF, and CAM. After EDTA treatment, cells of strain GK19 were induced with IPTG, and, at intervals, samples were added to tubes containing the inhibitors. The tubes were incubated for $20 \mathrm{~min}$ at $37 \mathrm{C}$ to allow complete expression of new enzyme synthesis. The final amounts of enzyme activity were measured and are shown in Fig. 6, as a function of the time at which various drug treatments were initiated.

Since CAM inhibits peptide bond synthesis, the CAM data represent the quantity of enzyme present at the time of addition of drugs

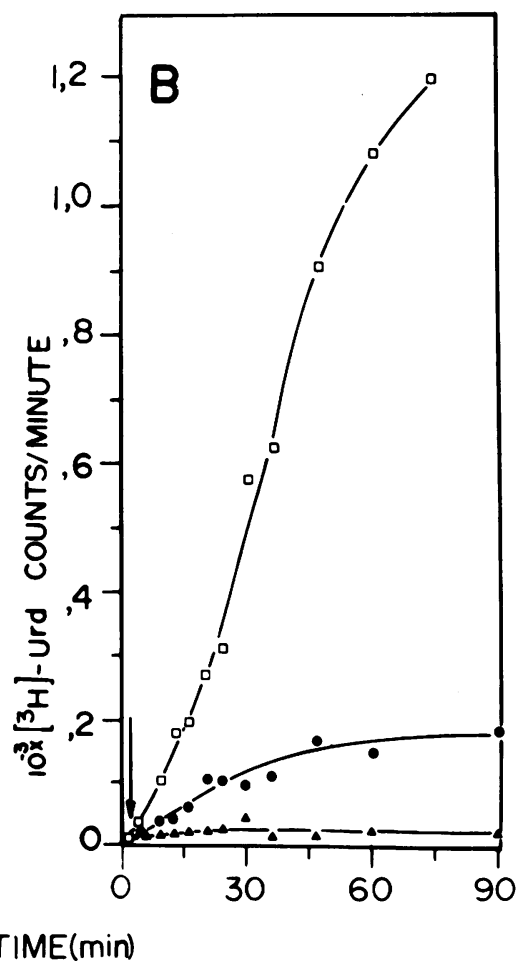

Fig. 5. Comparison of $\beta$-galactosidase synthesizing capacity of $E$. coli that was rendered permeable and then treated with RIF or TL. Cells of E. coli K-12 (GK19) grown in medium E-glycerol-B, were submitted to EDTA treatment and then diluted 10-fold in the original medium. Bacteria were induced with IPTG $\left(10^{-2} M\right)$ at time zero. Portions $(2 \mathrm{ml})$ of induced cultures were incubated in the presence of $\left[{ }^{3} \mathrm{H}\right]$ uridine. TL $(20 \mu \mathrm{g} / \mathrm{ml})$ and $R I F(7.5 \mu \mathrm{g} / \mathrm{ml})$ were added $2 \mathrm{~min}$ later (arrow). $\beta$-Galactosidase activity $(A)$ and trichloroacetic acidprecipitable radioactivity $(B)$ were determined at the indicated intervals. Symbols: untreated (controls) ( $\square)$, plus $T L(O)$, plus $R I F(\Delta)$. 


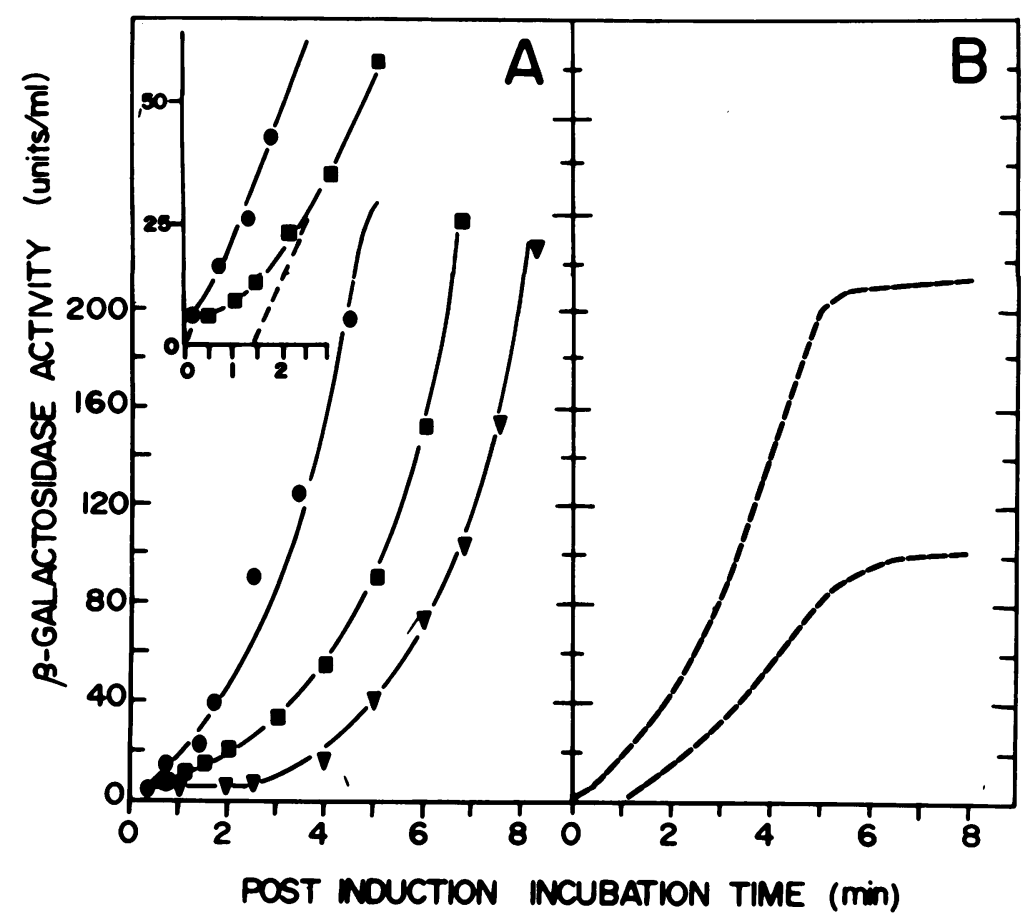

Fig. 6. Comparison of total residual $\beta$-galactosidase synthesized in the presence of RIF, TL, and CAM. Cells of strain GK19 were grown in medium E-glycerol- $B_{1}$ and were induced with IPTG (1 mM) at time zero. At

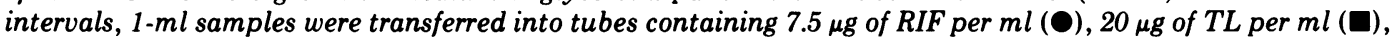
or $50 \mu \mathrm{g}$ of CAM per $\mathrm{ml}(\nabla)$. After incubation for a further $20 \mathrm{~min}, \beta$-galactosidase was assayed. $(A)$ This $\beta$-galactosidase activity is plotted versus time of transfer to drug-containing tubes. $(B)$ The difference between the data obtained in the presence of CAM and that obtained in the presence of RIF (upper curve) and TL (lower curve). The insert shows $\beta$-galactosidase activity during the first $3 \mathrm{~min}$ on an expanded scale.

(assuming all achieve maximal effect within a similar short interval of $20 \mathrm{~s}$, see above). The data presented in Fig. $6 \mathrm{~A}$ for $\beta$-galactosidase activity in the presence of CAM indicate that the first increment occurs at $3 \mathrm{~min}$. This value is consistent with that previously reported by Jacquet and Kepes (5). The difference between the CAM data and that obtained in the presence of RIF or TL (Fig. 6B) represents the result of all transcription and translation which occurs in their presence. Once a steady state is reached with maximal rate of transcription, this difference also becomes maximal, explaining the plateaus in the difference curves (Fig. 6B). If one assumes that RIF affects only the initiation of mRNA synthesis, an inhibitor of RNA polymerization added during steady state, when the rate of synthesis of $\beta$-galactosidase is maximal, should allow $50 \%$ as much synthesis after its addition as does RIF (see above). The relative heights of the RIF and TL plateaus are 100 and 45 , respectively, confirming that TL is an inhibitor of mRNA elongation.
Completion of transcription and translation of lac $z$ gene after brief blockage with TL. We took advantage of the rapid inhibition of RNA polymerization by TL to measure the in vivo stability of the complex of RNA polymerase, incomplete mRNA, and polysomes immobilized on the $z$ gene in the presence of TL. We determined the residual synthesis of $\beta$-galactosidase after a pulse induction and exposure to TL for varying periods of time. Cultures of strain GK19 were induced for a period of $20 \mathrm{~s}$ at $37 \mathrm{C}$. The induction was halted by diluting the cells $(1: 50)$ into prewarmed medium. TL was added at $1.5 \mathrm{~min}$, and in its presence residual enzyme synthesis was measured as a function of time (Fig. 7A). It comes to a halt in approximately $3 \mathrm{~min}$. This represents the amount of enzyme synthesized on lac $z$ gene mRNA completed at the time of TL addition.

After reversal of drug treatment by washing the cells free of TL, additional residual enzyme synthesis could result either from completion of incomplete but non-inactivated lac $z$ gene 


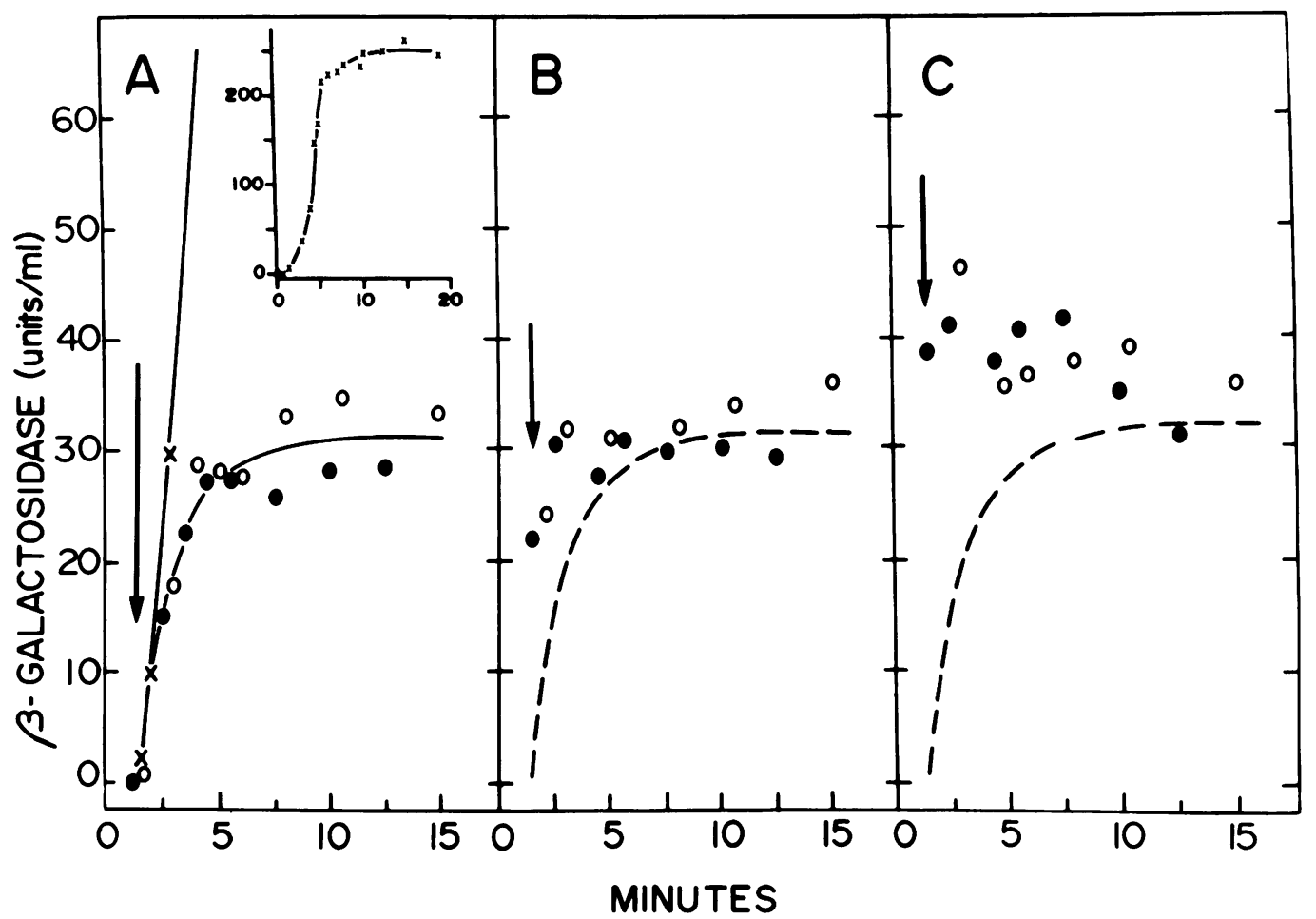

Fig. 7. Loss of incompletely transcribed $m R N A$ during recovery from $T L$ treatment. (O) and (O) represent results from two separate experiments. (A) Cells of strain GK19 were pulse-induced (20 s) with 10-3 M IPTG (X). At $1.5 \mathrm{~min}, T L(20 \mu \mathrm{g} / \mathrm{ml})$ was added (arrow), and the activity of $\beta$-galactosidase was assayed at the indicated intervals. (B) At the same intervals, samples were removed, washed free of $T L$, and resuspended in minimal medium $E$ lacking glycerol and Casamino Acids and containing CAM $(150 \mu \mathrm{g} / \mathrm{ml})$. $\beta$-Galactosidase was assayed 40 min later. $(C)$ At the same intervals, samples were washed free of $T L$, resuspended in complete medium, and incubated for a further $40 \mathrm{~min}$. The dashed line in $(B)$ and $(C)$ represents enzyme synthesis in cells continuously incubated with $T L$. Insert in $(A)$ shows the wave of $\beta$-galactosidase synthesis in an untreated control.

mRNAs, or from transcription of lac mRNA by RNA polymerase in a functional initiation complex at the lac promotor/operator region.

At 0.5 -min intervals, samples were removed from the TL-treated culture, rapidly washed free of the drug, and resuspended in $\mathrm{E}$ medium without carbon source or Casamino Acids and containing CAM (Fig. 7B) or in complete medium (Fig. 7C). After incubation for $40 \mathrm{~min}$, $\beta$-galactosidase was assayed. After very short pulses of TL and washing and suspension in medium containing CAM (Fig. 7B), an elevation in the enzyme level to $30 \mathrm{U}$, compared with the cultures remaining in TL (the dashed line, Fig. 7B), is seen. This enzyme synthesis must occur during the time from the start of washing to the time at which CAM exerts its full effect.

As shown in Fig. 7C, cells recovering from even short exposures to TL in the absence of CAM only synthesize small amounts of $\beta$-galactosidase above the level achieved in the contin- ual presence of TL. Measurement of enzyme synthesis after the briefest treatment was accomplished by filtering the cells through membrane filters covered with prewarmed medium containing TL. Thus, for the $1.5-\mathrm{min}$ data, represented as 0 -min exposure to $\mathrm{TL}$, washing and resuspension were completed in $20 \mathrm{~s}$. After addition of TL at $1.5 \mathrm{~min}$, the residual synthesis of $\beta$-galactosidase was $32 \mathrm{U}$ or $13 \%$ of the plateau level $(250 \mathrm{U})$ made in the untreated control (Fig. 7A). Cells receiving the briefest exposures to TL had residual synthesis of $\beta$ galactosidase of $45 \mathrm{U}$ (Fig. 7C) or $18 \%$ of the plateau level of the untreated control, only $5 \%$ above the unwashed samples. Thus, the lac $z$ gene transcription and initiation complexes decay very rapidly in the presence of TL.

\section{DISCUSSION}

The growth inhibitory action of TL has been 
attributed to its effect(s) on RNA synthesis in yeast $(6,25)$ and bacterial cells $(9 a)$. The data presented in the present paper indicate that this effect is due to inhibition of elongation of pre-initiated mRNA chains in $E$. coli without discernible effect on translation, and that this effect is very rapid. Thus, TL can be used to determine transcription times of inducible cistrons (cf. Fig. 4, insert) and the half-lives of their completed messengers (cf. Fig. 3B). The effect of TL is reversible by washing (Fig. 2), but transcription initiated before TL addition is not completed after its removal (Fig. 7). TL, therefore, cannot be used to measure the halflife of a particular mRNA during transcription of its cistron, and the effect of TL may be to cause disintegration of transcriptional complexes.

As treatment of purified $\beta$-galactosidase with TL does not alter its catalytic activity (Fig. 1) and protein synthesis is also unaffected in vivo (Fig. 3,5 ) and in vitro (6) by TL, we suspect that its effect is not a general and nonspecific one on enzyme action. Furthermore, since the half-life of preformed mRNA in the presence of TL, deduced from the data in Fig. 3 and 6 , is consistent with earlier estimates $(9,23)$, the bacteriostatic effect of TL cannot be attributed to accelerated breakdown of mRNA. The most plausible explanation, consistent with the in vitro studies on yeast RNA polymerase (25), is that TL interacts with or modifies a component of the transcriptional machinery of sensitive cells, for example by acting as an analogue of its ribonucleotide triphosphate substrates. However, this could occur at a variety of levels, e.g., interaction with one of the four subunits, $\alpha, \beta, \beta^{\prime}$, and $\sigma$ of RNA polymerase holoenzyme or with additional regulatory subunits involved with transcription of the bacterial genome $(2,22)$. Further biochemical and genetic data are needed before the mechanism of action of TL can be further defined; however, the ease with which TL penetrates $E$. coli cells and the rapidity and reversibility of its action suggest that it will be a most useful tool in physiological studies in bacteria.

\section{ACKNOWLEDGMENTS}

We thank Nathan Belcher for the gift of thiolutin. We also thank Elizabeth Duhamel and Lorraine McGrath for technical assistance.

This study was supported by Public Health Service grants AI-10806 and GM-20755 from the National Institute of Allergy and Infectious Diseases and the National Institute of General Medical Sciences, respectively.

\section{LITERATURE CITED}

1. Fan, D. P. 1966. Decay of intact messengers in bacteria. J. Mol. Biol. 16:164-179.

2. Geiduschek, E. P., and R. Haselkorn. 1969. Messenger RNA. Annu. Rev. Biochem. 38:647-677.

3. Hall, B. G., and J. A. Gallant. 1973. On the rate of messenger decay during amino acid starvation. J. Mol. Biol. 73:121-124.

4. Jacquet, M., and A. Kepes. 1969. The step sensitive to catabolite repression and its reversal by $3^{\prime}-5$ ' cyclic AMP during induced synthesis of $\beta$-galactosidase in $E$. coli. Biochem. Biophys. Res. Commun. 36:84-92.

5. Jacquet, M., and A. Kepes. 1971. Initiation, elongation and inactivation of lac mRNA in $E$. coli studied by measurement of its $\beta$-galactosidase synthesizing capacity in vivo. J. Mol. Biol. 60:453-472.

6. Jimenez, A., D. J. Tipper, and J. Davies. 1973. Mode of action of thiolutin, an inhibitor of macromolecular synthesis in Saccharomyces cerevisiae. Antimicrob. Ag. Chemother. 3:729-738.

7. Kennell, D., and J. Bicknell. 1973. Decay of messenger ribonucleic acid from the lactose operon of Escherichia coli as a function of growth temperature. J. Mol. Biol. 74:21-31.

8. Kepes, A. 1963. Kinetics of induced enzyme synthesis. Determination of the mean life of galactosidase-specific messenger RNA. Biochim. Biophys. Acta 76:293-309.

9. Kepes, A. 1969. Transcription and translation in the lactose operon of Escherichia coli studied by in vivo kinetics. Progr. Biophys. Mol. Biol. 19:199-236.

9a. Khachatourians, G. G., and D. J. Tipper. 1974. In vivo effect of thiolutin on cell growth and macromolecular synthesis in Escherichia coli. Antimicrob. Ag. Chemother., Vol. 6.

10. Kuwano, M., C. N. Kwan, D. Apirion, and D. Schlessinger. 1969. Ribonuclease V of Escherichia coli. I. Dependence on ribosomes and translocation. Proc. Nat. Acad. Sci. U.S.A. 64:693-700.

11. Lark, K. G. 1972. Evidence for the direct involvement of DNA in the initiation of DNA replication in $E$ scherichia coli 15T- ${ }^{-}$. J. Mol. Biol. 64:47-60.

12. Leive, L. 1965. Actinomycin sensitivity in Escherichia coli produced by EDTA. Biochem. Biophys. Res. Commun. 18:13-17.

13. Leive, L. 1965. Some effects of inducer on synthesis and utilization of $\beta$-galactosidase messenger RNA in actinomycin-sensitive Escherichia coli. Biochem. Biophys. Res. Commun. 20:321.

14. Matzura, H., S. Molin, and O. Maaloe. 1971. Sequential biosynthesis of the $\beta$ and $\beta^{\prime}$ subunits of the DNAdependent RNA polymerase from Escherichia coli. J. Mol. Biol. 59:17-25.

15. Miller, J. H. 1972. Experiments in molecular genetics. Cold Spring Harbor Laboratory, Cold Spring Harbor, N.Y.

16. Morikawa, N., and F. Imamoto. 1969. On the degradation of messenger RNA for the tryptophan operon in Escherichia coli. Nature (London) 223:37-40.

17. Morse, D. E., R. D. Mosteller, and C. Yanofsky. 1969. Dynamics of synthesis, translation and degradation of trp operon messenger RNA in $E$. coli. Cold Spring Harbor Symp. Quant. Biol. 34:725-740.

18. Pardee, A., and L. Prestidge. 1961. The initial kinetics of enzyme induction. Biochim. Biophys. Acta 49:77-88.

19. Pato, M. L., P. M. Bennett, and K. von Meyenberg. 1973. Messenger ribonucleic acid synthesis and degradation in Escherichia coli during inhibition of translation. J. Bacteriol. 116:710-718.

20. Reid, P., and J. Speyer. 1970. Rifampicin inhibition of RNA and protein synthesis in normal and ethylenediaminetetraacetic acid-treated $\boldsymbol{E}$. coli. J. Bacteriol. 
104:376-389.

21. Rogerson, A. C., and D. H. Ezekiel, 1974. Decay of ribonucleic acid synthesis in amino acid-starved Escherichia coli after rifampicin treatment. J. Bacteriol. 117:987-993.

22. Scaife, J. G. 1973. Control of transcription in bacteria. Brit. Med. Bull. 29:214-219.

23. Schwartz, T., E. Craig, and D. Kennell. 1970. Inactivation and degradation of messenger ribonucleic acid from the lactose operon of Escherichia coli. J. Mol. Biol. $54: 299-311$.

24. Silvestri, L. G., and G. Lancinini. 1972. Rifamycin (a general view). Annu. Rev. Microbiol. 26:199-224.
25. Tipper, D. J. 1973. Inhibition of yeast ribonucleic acid polymerases by thiolutin. J. Bacteriol. 116:24-256.

26. Varmus, H. E., R. L. Perlman, and I. Pastan. 1971. Regulation of lac transcription in antibiotic-treated $E$. coli. Nature N. Biol. 230:41-44.

27. Vogel, M. J., and D. Bonner. 1956. Acetylornithinase of E. coli. Partial purification and time properties. J. Biol. Chem. 218:97-106.

28. Zabin, I., and A. C. Fowler. 1970. $\beta$-galactosidase and thiogalactoside transacetylase, p. 27-47. In J. R. Beckwith and D. Zipser (ed.), The lactose operon. Cold Spring Harbor Laboratory, Cold Spring Harbor, N.Y. 